\title{
Clinical and Laboratory Diagnosis of Heparin-Induced Thrombocytopenia: An Integrated Approach
}

\author{
Adam Cuker, MD, MS ${ }^{1}$ \\ ${ }^{1}$ Department of Medicine and Department of Pathology and \\ Laboratory Medicine, Perelman School of Medicine, University of \\ Pennsylvania, Philadelphia, Pennsylvania \\ Semin Thromb Hemost 2014;40:106-114.
}

\begin{abstract}
Address for correspondence Adam Cuker, MD, MS, Department of Medicine and Department of Pathology \& Laboratory Medicine, Perelman School of Medicine, University of Pennsylvania, HUP, 3 Dulles, 3400 Spruce Street, Philadelphia, PA 19104 (e-mail: adam.cuker@uphs.upenn.edu).
\end{abstract}

\begin{abstract}
Keywords

- heparin-induced thrombocytopenia

- HIT

- diagnosis

Heparin-induced thrombocytopenia (HIT) is a clinicopathologic disorder that predisposes to thrombosis. Diagnosis rests on a compatible clinical picture and laboratory evidence of antiplatelet factor 4 (PF4)/heparin antibodies that activate platelets in a heparin-dependent manner. Rapid and accurate diagnosis is paramount to avoid the perils of misdiagnosis. Clinical evaluation may be guided by scoring systems such as the 4Ts and HIT Expert Probability (HEP) score. Laboratory tests include immunoassays, such as the PF4/heparin enzyme-linked immunosorbent assay (ELISA) and functional tests such as the ${ }^{14} \mathrm{C}$-serotonin release assay and heparin-induced platelet activation assay. Clinical scoring systems and commercially available immunoassays have high sensitivity but modest specificity. Functional assays are more specific, but they are technically demanding. Novel laboratory assays with faster turnaround times, greater specificity, and lesser technical complexity are in development. A Bayesian approach that combines the 4T score and the PF4/heparin ELISA result may be used to estimate the probability of HIT and guide clinical decision making.
\end{abstract}

Heparin-induced thrombocytopenia (HIT) is a prothrombotic disorder mediated by platelet, leukocyte, and endothelial cellactivating antibodies that recognize ultralarge complexes of platelet factor 4 (PF4) and heparin. ${ }^{1-4}$ Management entails cessation of heparin and initiation of a nonheparin parenteral anticoagulant. $^{5-7}$

Whether to discontinue heparin and begin a nonheparin anticoagulant in a patient with suspected HIT is a high stakes decision. Delays in implementing therapy in patients with serologically confirmed HIT are associated with an initial $6.1 \%$ daily risk of thromboembolism, amputation, and death ${ }^{8}$ and a cumulative thrombotic risk of 38 to $53 \%$ at 30 days. ${ }^{9,10}$ On the contrary, treatment for HIT carries certain risks. ${ }^{11}$ Licensed drugs (argatroban, danaparoid, and lepirudin) are associated with a $\sim 1.0 \%$ daily risk of major hemorrhage. ${ }^{12-14}$ Bleeding risk may be greater still in patients misdiagnosed with HIT whose thrombocytopenia is due to a hemorrhagic rather than a prothrombotic

published online December 21, 2013
Issue Theme Hot Topics V; Guest Editor, Emmanuel J. Favaloro, PhD, FFSc (RCPA). diathesis and is compounded by absence of effective reversal agents. Rapid and accurate diagnosis is therefore paramount to avoid the perils of both diagnostic delay and misdiagnosis.

HIT is a clinicopathologic diagnosis, which rests on both a compatible clinical picture and laboratory demonstration of heparin-dependent cell-activating anti-PF4/heparin antibodies. ${ }^{15}$ The objectives of this article are to review currently available tools for clinical and laboratory diagnosis, discuss their limitations, highlight novel tests in development, and propose an evidence-based Bayesian approach for the diagnosis of patients with suspected HIT that integrates clinical evaluation and laboratory testing.

\section{Clinical Diagnosis}

The cardinal clinical feature of HIT is a fall in platelet count in the setting of a proximate heparin exposure. This scenario
Copyright $\odot 2014$ by Thieme Medical Publishers, Inc., 333 Seventh Avenue, New York, NY 10001, USA. Tel: +1(212) 584-4662.
DOI http://dx.doi.org/ $10.1055 / \mathrm{s}-0033-1363461$. ISSN 0094-6176. 
Table 1 Clinical features that support a diagnosis of heparin-induced thrombocytopenia

\begin{tabular}{|l|l|}
\hline Features & Comments \\
\hline Fall in platelet count $\geq 50 \%$ & $\begin{array}{l}\text { Measured from peak platelet count after heparin exposure to } \\
\text { nadir platelet count. }\end{array}$ \\
\hline $\begin{array}{l}\text { Fall in platelet count begins } 5 \text { to } 14 \text { days after initial } \\
\text { heparin exposure }\end{array}$ & $\begin{array}{l}\text { Fall may occur immediately after heparin re-exposure in patients } \\
\text { with a previous recent exposure. }\end{array}$ \\
\hline Nadir platelet count $\geq 20 \times 10^{9} / \mathrm{L}$ & $\begin{array}{l}\text { Median nadir platelet count is } \sim 60 \times 10^{9} / \mathrm{L} . \text { Nadir may be } \\
<20 \times 10^{9} / \mathrm{L} \text { in cases associated with disseminated intravas- } \\
\text { cular coagulation. }\end{array}$ \\
\hline Thromboembolism & May be venous or arterial. \\
\hline Unusual clinical manifestations & $\begin{array}{l}\text { Skin necrosis at subcutaneous heparin injection sites; anaphy- } \\
\text { lactoid reactions after intravenous heparin bolus; transient } \\
\text { global amnesia }\end{array}$ \\
\hline Absence of petechiae and other significant bleeding & \\
\hline Absence of alternative causes of thrombocytopenia & $\begin{array}{l}\text { Such as infection, drugs other than heparin, recent cardiopul- } \\
\text { monary bypass, etc. }\end{array}$ \\
\hline
\end{tabular}

has poor positive predictive value for HIT owing to the ubiquity of heparin use and thrombocytopenia in hospitalized patients. In a multicenter registry of 2,420 primarily medical patients treated with heparin for 4 or more days, thrombocytopenia occurred in $36.4 \%{ }^{16}$ although the incidence of HIT in heparin-treated medical patients is only 0 to $0.8 \%{ }^{17-20}$ Thrombocytopenia is present in 8.3 to $67.6 \%$ of patients on admission to an intensive care unit (ICU) and an additional 13.0 to $44.1 \%$ acquire thrombocytopenia during their ICU course. ${ }^{21}$ At least a quarter of these patients have a history of recent heparin exposure, ${ }^{22}$ although the incidence of HIT in the critically ill is only 0.3 to $0.6 \% .^{23-25}$ Thus, thrombocytopenia in the vast majority of hospitalized patients with heparin exposure is due to an etiology other than HIT. The great challenge confronting clinicians is to distinguish the relatively uncommon patient with HIT who requires prompt discontinuation of heparin and initiation of a nonheparin anticoagulant from the far more prevalent patient who is thrombocytopenic for other reasons and could be harmed by unnecessary withdrawal of heparin therapy and treatment for HIT. ${ }^{6}$
Careful consideration of additional clinical features is necessary to distinguish HIT from other etiologies of thrombocytopenia. These features are summarized in - Table 1 and are reviewed elsewhere. ${ }^{6,26}$ Incorporating these complex features in an estimate of clinical (i.e., pretest) probability can be challenging. To assist clinicians in this process, several clinical scoring systems for HIT have been developed.

\section{Ts Score}

The most extensively studied scoring system, the 4Ts, incorporates four clinical features: (1) magnitude of thrombocytopenia, (2) timing of onset of thrombocytopenia, (3) thrombosis or other clinical sequelae, and (4) the likelihood of other causes of thrombocytopenia. Each feature is assigned a score of 0,1 , or 2 points, yielding a maximum possible summative score of 8 . Total scores of 0 to 3,4 to 5 , and 6 to 8 correspond to low, intermediate, and high pretest probabilities, respectively.

Since its initial description, ${ }^{27}$ the 4 Ts has undergone several modifications. The most widely used version ( - Table 2$)^{28}$ has been evaluated in various clinical settings. In a meta-analysis of 13 studies, the negative predictive value

Table 2 4Ts score

\begin{tabular}{|l|l|l|l|}
\hline Category & $\mathbf{2}$ points & $\mathbf{1}$ point & $\mathbf{0}$ points \\
\hline 1. Thrombocytopenia & $\begin{array}{l}\text { Platelet count fall }>50 \% \text { and } \\
\text { platelet nadir } \geq 20 \times 10^{9} / \mathrm{L}\end{array}$ & $\begin{array}{l}\text { Platelet count fall } 30-50 \% \text { or } \\
\text { platelet nadir } 10-19 \times 10^{9} / \mathrm{L}\end{array}$ & $\begin{array}{l}\text { Platelet count fall }<30 \% \text { or } \\
\text { platelet nadir }<10 \times 10^{9} / \mathrm{L}\end{array}$ \\
\hline $\begin{array}{l}\text { 2. Timing of platelet } \\
\text { count fall }\end{array}$ & $\begin{array}{l}\text { Clear onset between days } 5 \text { and } \\
10 \text { or platelet fall } \leq 1 \text { day (prior } \\
\text { heparin exposure within 30 days) }\end{array}$ & $\begin{array}{l}\text { Consistent with days } 5-10 \text { fall, } \\
\text { but not clear (e.g., missing } \\
\text { platelet counts) or onset after } \\
\text { day 10 or fall } \leq 1 \text { day (prior hep- } \\
\text { arin exposure 30-100 days ago) }\end{array}$ & $\begin{array}{l}\text { Platelet count fall }<4 \text { days } \\
\text { without recent heparin } \\
\text { exposure }\end{array}$ \\
\hline $\begin{array}{l}\text { 3. Thrombosis or } \\
\text { other sequelae }\end{array}$ & $\begin{array}{l}\text { New thrombosis (confirmed) or } \\
\text { skin necrosis at heparin injection } \\
\text { sites or acute systemic reaction } \\
\text { after intravenous heparin bolus }\end{array}$ & $\begin{array}{l}\text { Progressive or recurrent throm- } \\
\text { bosis or non-necrotizing (ery- } \\
\text { thematous) skin lesions or } \\
\text { suspected thrombosis (not } \\
\text { proven) }\end{array}$ & None \\
\hline $\begin{array}{l}\text { 4. Other causes for } \\
\text { thrombocytopenia }\end{array}$ & None apparent & Possible & Definite \\
\hline
\end{tabular}


of a low probability 4Ts score was 99.8\% (95\% CI: 97.0-100.0\%) and remained high irrespective of the party responsible for scoring, the prevalence of HIT, or the composition of the study population. The positive predictive value of an intermediate
(14\%, 9-22\%) and high probability 4Ts score $(64 \%, 40-82 \%)$ was more modest. ${ }^{29}$ Limitations in interobserver reliability of the 4Ts system have also been noted with $\mathrm{k}$ coefficients ranging between 0.5 and $0.7 .^{30-32}$

Table 3 HIT Expert Probability (HEP) Score

\begin{tabular}{|c|c|}
\hline Clinical features & Points \\
\hline \multicolumn{2}{|l|}{$\begin{array}{l}\text { 1. Magnitude of fall in platelet count } \\
\text { (measured from peak platelet count to nadir platelet count since heparin exposure) }\end{array}$} \\
\hline$<30 \%$ & -1 \\
\hline $30-50 \%$ & 1 \\
\hline$>50 \%$ & 3 \\
\hline \multicolumn{2}{|l|}{ 2. Timing of fall in platelet count } \\
\hline \multicolumn{2}{|l|}{ For patients in whom typical onset HIT is suspected } \\
\hline Fall begins $<4$ days after heparin exposure & -2 \\
\hline Fall begins 4 days after heparin exposure & 2 \\
\hline Fall begins 5-10 days after heparin exposure & 3 \\
\hline Fall begins $11-14$ days after heparin exposure & 2 \\
\hline Fall begins $>14$ days after heparin exposure & -1 \\
\hline \multicolumn{2}{|c|}{ For patients with heparin exposure in past 100 days in whom rapid onset HIT is suspected } \\
\hline Fall begins $\leq 48$ hours after heparin re-exposure & 2 \\
\hline Fall begins $>48$ hours after heparin re-exposure & -1 \\
\hline \multicolumn{2}{|l|}{ 3. Nadir platelet count } \\
\hline$\leq 20 \times 10^{9} / \mathrm{L}$ & -2 \\
\hline$>20 \times 10^{9} / \mathrm{L}$ & 2 \\
\hline \multicolumn{2}{|l|}{ 4. Thrombosis (select no more than one) } \\
\hline \multicolumn{2}{|l|}{ For patients in whom typical onset HIT is suspected } \\
\hline New VTE or ATE occurring $\geq 4$ days after heparin exposure & 3 \\
\hline Progression of preexisting VTE or ATE while receiving heparin & 2 \\
\hline \multicolumn{2}{|c|}{ For patients with heparin exposure in past 100 days in whom rapid onset HIT is suspected } \\
\hline New VTE or ATE after heparin exposure & 3 \\
\hline Progression of preexisting VTE or ATE while receiving heparin & 2 \\
\hline \multicolumn{2}{|l|}{ 5. Skin necrosis } \\
\hline Skin necrosis at subcutaneous heparin injection sites & 3 \\
\hline \multicolumn{2}{|l|}{ 6. Acute systemic reaction } \\
\hline Acute systemic reaction following intravenous heparin bolus & 2 \\
\hline \multicolumn{2}{|l|}{ 7. Bleeding } \\
\hline Presence of bleeding, petechiae, or extensive bruising & -1 \\
\hline \multicolumn{2}{|l|}{ 8. Other causes of thrombocytopenia (Select all that apply) } \\
\hline Presence of a chronic thrombocytopenic disorder & -1 \\
\hline Newly initiated nonheparin medication known to cause thrombocytopenia & -2 \\
\hline Severe infection & -2 \\
\hline Overt DIC (defined as fibrinogen $<100 \mathrm{mg} / \mathrm{dL}$ and D-dimer $>5.0 \mu \mathrm{g} / \mathrm{mL}$ ) & -2 \\
\hline Indwelling intra-arterial device (e.g., IABP, VAD, and ECMO) & -2 \\
\hline Cardiopulmonary bypass within previous 96 hours & -1 \\
\hline No other apparent cause & 3 \\
\hline
\end{tabular}

Abbreviations: ATE, arterial thromboembolism; DIC, disseminated intravascular coagulation; ECMO, extracorporeal membrane oxygenation; IABP, intra-aortic balloon pump; VAD, ventricular-assist device; VTE, venous thromboembolism. 


\section{HIT Expert Probability Score}

The HIT Expert Probability (HEP) score is based on the opinions of clinical HIT experts from North America. It comprises 8 clinical features including magnitude of platelet count fall, timing of platelet count fall, nadir platelet count, thrombosis, skin necrosis, acute systemic reaction, bleeding, and other causes of thrombocytopenia (-Table 3 ). Integral weights ranging from -3 (argues strongly against HIT) to +3 (argues strongly in favor of HIT) are assigned to each feature and correspond to the median opinions of the 26 experts on which the model is based. In a retrospective single center study, a cutoff score of 5 was associated with a positive predictive value of $55 \%(25-82 \%)$ and a negative predictive value of $97 \%(85-100 \%),{ }^{30}$ operating characteristics similar to those observed with the $4 \mathrm{Ts}^{29}$ The HEP score is more complex and may be more time consuming to apply than the 4Ts. It has not undergone prospective evaluation and definitive cutoffs have not been established. Retrospective comparisons of the HEP score and 4Ts have not demonstrated a significant difference in performance between the two models. $^{33,34}$

\section{Other Scoring Systems}

Several other pretest scoring systems for HIT have been developed but have not been prospectively evaluated..$^{35,36}$ The Lillo-Le Louët score was designed to estimate the probability of HIT in patients following cardiopulmonary bypass (CPB). The model incorporates 3 variables that were predictive of HIT in a derivation set (a biphasic platelet count profile, an interval of $\geq 5$ days from CPB to the first day of suspected HIT, and a CPB duration of $\geq 118$ minutes). ${ }^{35}$ In an independent study, it showed a negative predictive value of $78 \%$, suggesting that it may have inadequate sensitivity for use as a clinical screening test. ${ }^{37}$

\section{Laboratory Diagnosis}

In light of the challenges of clinical diagnosis, physicians rely heavily on laboratory testing, although this too has (often underrecognized) limitations. Laboratory tests for HIT may be divided into two categories: immunoassays and functional assays. Characteristics of these assays are summarized in - Table $\mathbf{4}$ and reviewed in detail later.

\section{Immunoassays}

Only a subset of anti-PF4/heparin antibodies has the capacity to activate cells and cause HIT. Commercially available immunoassays detect circulating anti-PF4/heparin antibodies but fail to distinguish cell-activating and potentially pathogenic antibodies from their nonpathogenic counterparts. This property of immunoassays underlies their operating characteristics: high sensitivity and limited specificity.

The prototypical immunoassay is the polyspecific PF4/ heparin (or PF4/polyvinylsulfonate) solid phase enzymelinked immunosorbent assay (ELISA), which detects circulating anti-PF4/heparin IgG, IgM, and IgA. ${ }^{1}$ At the manufacturerrecommended optical density (OD) cutoff, the sensitivity and specificity of this test are 94 to $100 \%$ and 81 to $93 \%$, respectively. ${ }^{38-41}$

Specificity may be improved by raising the OD cutoff. OD is directly associated with the 4Ts and HEP score, ${ }^{30}$ risk of thrombosis, ${ }^{42}$ and likelihood of a positive functional assay. ${ }^{43}$ In a Canadian study, only 1 of 37 patient samples exhibiting a weakly positive OD (0.40-0.99) demonstrated heparindependent platelet activation in contrast to 33 of 37 samples with a strongly positive $\mathrm{OD}(\geq 2.0) .{ }^{43}$ In an analysis of 1,958 patients who underwent HIT laboratory testing in a single reference laboratory, HIT was defined as an intermediate or high clinical suspicion coupled with a positive functional assay. Increasing the cutoff from a manufacturer-recommended threshold of 0.4 to 0.8 OD units in this test population improved specificity from 85 to $93 \%$ with a slight reduction in sensitivity from 100 to $98 \%$. OD strata of $<0.60,0.60-1.49,1.50-1.99$, and $\geq 2.00$ were associated with likelihood ratios of $0,1.2,7.0$, and 72.0 , respectively. ${ }^{44}$

Several modifications have been made to the PF4/heparin ELISA with the goal of improving specificity. Because the majority of pathogenic antibodies are of the IgG class, detection systems specific for IgG have been developed. In a pooled analysis of studies comparing the IgG-specific and the polyspecific ELISA, the former showed greater specificity ( $93.5 \mathrm{vs.}$ $89.4 \%$ ), but at the cost of reduced sensitivity (95.8 vs. $98.1 \%$ ). ${ }^{45}$ Another modification involves the addition of a high heparin confirmatory step, in which reduction of the OD by $\geq 50 \%$ with addition of excess heparin (usually $100 \mathrm{U} / \mathrm{mL}$ ) is considered to affirm the presence of heparin-dependent antibodies. ${ }^{46}$ This method marginally improves specificity, but false-positive

Table 4 General characteristics of diagnostic laboratory assays for HIT

\begin{tabular}{|l|l|l|l|l|}
\hline Category & Principles & Examples & Advantages & Disadvantages \\
\hline Immunoassays & $\begin{array}{l}\text { Detect circulating PF4/hep- } \\
\text { arin antibodies, irrespective } \\
\text { of their capacity to activate } \\
\text { cells }\end{array}$ & $\begin{array}{l}\text { Polyspecific ELISA } \\
\text { IgG-specific ELISA }\end{array}$ & $\begin{array}{l}\text { High sensitivity, } \\
\text { simple to perform, and } \\
\text { widely available }\end{array}$ & Limited specificity \\
\hline Functional assays & $\begin{array}{l}\text { Detect antibodies that acti- } \\
\text { vate cells in a heparin-de- } \\
\text { pendent manner }\end{array}$ & $\begin{array}{l}\text { SRA } \\
\text { HIPA }\end{array}$ & $\begin{array}{l}\text { High sensitivity and } \\
\text { high specificity }\end{array}$ & $\begin{array}{l}\text { Technically difficult } \\
\text { and limited } \\
\text { availability }\end{array}$ \\
\hline
\end{tabular}

Abbreviations: ELISA, enzyme-linked immunosorbent assay; HIT, heparin-induced thrombocytopenia; HIPA, heparin-induced platelet activation assay; $\mathrm{IgG}$, immunoglobulin G; PF4, platelet factor 4; SRA, ${ }^{14} \mathrm{C}$-serotonin release assay. 
results remain common and false-negatives may also occur, particularly at high OD values. ${ }^{47,48}$

It was recently observed that cell-activating and potentially pathogenic antibodies differ from nonpathogenic antibodies with respect to the epitopes to which they bind PF4/ heparin complexes. ${ }^{49}$ A competitive ELISA that uses KKO, a HIT-like murine monoclonal anti-PF4/heparin IgG, has been developed to exploit this difference. Human cell-activating antibodies inhibit binding of KKO to immobilized PF4/heparin complexes, presumably by competing for the same or overlapping epitopes. Nonactivating human antibodies, in contrast, do not affect KKO binding. In samples from 58 patients with circulating anti-PF4/heparin antibodies, HIT-positive plasma demonstrated greater mean inhibition of KKO binding than HIT-negative plasma (78.9 vs. $26.0 \%, p<0.0001$ ). The competitive ELISA showed greater discrimination than the polyspecific or IgG-specific ELISA and may enable discrimination of cell-activating and potentially pathogenic antibodies from nonpathogenic antibodies using an ELISA platform. ${ }^{50}$

An important limitation of the PF4/heparin ELISA is its turnaround time (TAT). Although the analytical TAT is approximately 2 hours, the assay is most cost-effective when multiple patient samples are accommodated in a single run. Many laboratories therefore batch samples and perform the assay no more than once or twice a week, leaving clinicians to make critical initial management decisions without the benefit of laboratory results.

Several rapid immunoassays, designed to accommodate single patient samples and yield results in minutes, have been developed. These include a lateral flow immunoassay using gold nanoparticles, ${ }^{51}$ a particle gel immunoassay, ${ }^{51-53}$ a latex particle-enhanced immunoturbidimetric assay, ${ }^{54,55}$ and a polyspecific and IgG-specific chemiluminescence assay. ${ }^{55-57}$ Characteristics of these assays are summarized in - Table 5. The principles on which they are based are reviewed elsewhere. ${ }^{58}$ All have a TAT of 30 minutes or less and high sensitivity. The particle gel immunoassay appears to have a lower sensitivity (91-94\%) than the PF4/heparin ELISA. ${ }^{51,53}$ A negative result may therefore not be sufficient to exclude HIT, particularly if the clinical probability is high. Studies in single reference laboratories suggest that the lateral flow immunoassay $^{51}$ and IgG-specific chemiluminescence assay ${ }^{55}$ may have greater specificity than the IgG-specific PF4/heparin ELISA. Confirmation in other laboratories is required. The latex particle-enhanced immunoturbidimetric assay and chemiluminescence assays are instrument-based and must be performed on proprietary analyzers. A rapid particle immunofiltration assay is approved in the Unites States, but published data suggest that it has unacceptable diagnostic accuracy and experts do not recommend its use. ${ }^{59}$

\section{Functional Assays}

Functional assays are more specific than commercially available immunoassays because they detect only the subset of antibodies that have the capacity to induce platelet activation in a heparin-dependent manner. The prototypical functional assays are the ${ }^{14} \mathrm{C}$-serotonin release assay (SRA) and the heparin-induced platelet activation assay (HIPA). In the SRA, various concentrations of heparin and heat-inactivated patient serum are added to washed donor platelets radiolabeled with ${ }^{14} \mathrm{C}$. A positive test is signified by heparindependent release of ${ }^{14} \mathrm{C}$-serotonin. ${ }^{60}$ The HIPA is based on a similar principle but uses visual assessment of platelet aggregation as an endpoint. ${ }^{61}$ The sensitivity and specificity of the SRA and HIPA are said to exceed 95\%, although universally accepted reference standards against which to measure their performance do not exist. ${ }^{6}$ Other washed platelet assays that use ATP release detected by lumiaggregometry, ${ }^{62}$ platelet-derived microparticle generation detected by flow cytometry, ${ }^{63}$ and proteolysis of FcrRIIa (the receptor through which HIT immune complexes activate platelets) detected by chemiluminescence ${ }^{64}$ have been described but require independent validation.

Assays that use citrated platelet-rich plasma (PRP) rather than washed platelets include the platelet aggregation test $(\mathrm{PAT})^{65}$; a modification of the ${ }^{14} \mathrm{C}-\mathrm{SRA} \mathrm{A}^{66}$; and flow cytometrybased assays that use annexin V-binding, ${ }^{67}$ serotonin release, ${ }^{68}$ P-selectin expression, ${ }^{69}$ or platelet microparticle formation $^{70}$ as a readout. Studies comparing the PAT with a washed platelet assay suggest that the former has lower

Table 5 Characteristics of rapid immunoassays for the diagnosis of HIT

\begin{tabular}{|c|c|c|c|c|c|}
\hline Assay & Antibody class detection & Sensitivity & Specificity & $\begin{array}{l}\text { Turnaround } \\
\text { time (minutes) }\end{array}$ & $\begin{array}{l}\text { Regulatory } \\
\text { approval }\end{array}$ \\
\hline Lateral flow immunoassay ${ }^{51}$ & $\lg G$ & 1.00 & 0.93 & 15 & Europe \\
\hline Particle gel immunoassay ${ }^{51-53}$ & $\lg G$ & $0.91-0.94$ & $0.87-0.95$ & 20 & $\begin{array}{l}\text { Asia, Canada, } \\
\text { Europe }\end{array}$ \\
\hline $\begin{array}{l}\text { Latex particle-enhanced im- } \\
\text { munoturbidimetric assay } 54,55\end{array}$ & $\lg G, \lg A, \lg M$ & 1.00 & 0.76 & 13 & Europe \\
\hline $\begin{array}{l}\text { Chemiluminescence } \\
\text { assay }{ }^{55-57}\end{array}$ & $\lg G, \lg A, \lg M$ & $0.98-1.00$ & $0.73-0.82$ & 30 & Europe \\
\hline $\begin{array}{l}\text { Chemiluminescence } \\
\text { assay }{ }^{55-57}\end{array}$ & $\lg G$ & $0.96-1.00$ & $0.85-0.97$ & 30 & Europe \\
\hline
\end{tabular}

Abbreviation: HIT, heparin-induced thrombocytopenia. 
sensitivity (33\% to $81 \%$ ) and may miss cases of true HIT. $65,71,72$ For this reason, an international consensus panel recommends against use of the PAT. ${ }^{15}$ Comparisons between washed platelet assays and other PRP-based tests are lacking. A whole blood assay that uses impedance platelet aggregometry has also been described. This system demonstrated a sensitivity and specificity of 90.3 and $89.0 \%$, respectively, in a multicenter Australian study. ${ }^{73}$

The major disadvantage of washed platelet assays is that they are technically demanding. ${ }^{74}$ Both the SRA and HIPA require fresh reactive donor platelets, the SRA requires radioisotope, and the HIPA relies on meticulous technique, and the use of a subjective visual endpoint. These reagents and methods are impracticable for most clinical laboratories and restrict the use of functional assays to a small number of reference laboratories. Even among such laboratories, test methodologies, result interpretation, and reporting are not well-standardized. ${ }^{75}$

A novel functional assay that may overcome technical limitations inherent to washed platelet assays was recently described. The assay utilizes a chicken B-lymphocyte line transfected with the human FcrRIIa receptor coupled to a luciferase reporter. When appropriate concentrations of PF4, heparin, and dilute HIT plasma are added to the system, HIT immune complexes bind to the receptor and induce an intracellular signaling cascade, ultimately leading to luciferase activation and emission of light. ${ }^{76}$ In a study of this assay in 58 patients with suspected HIT and circulating PF4/heparin antibodies, SRA-positive plasma induced significantly greater mean luciferase activity than SRA-negative plasma (3.14-fold basal vs. 0.96 -fold basal, $p<0.0001$ ). Using a positive SRA and an intermediate or high probability 4Ts score as the reference standard, the assay correctly classified more patients $(51 / 58)$ than a commercially available polyspecific $(45 / 58)$ or IgG-specific (42/58) ELISA. $^{50}$ It may be feasibly employable in a greater number of clinical laboratories than the SRA or HIPA because it replaces platelets with a cell-line that can be stored in a freezer and retrieved for use as needed and uses light emission, rather than radioactivity or platelet aggregation, as an endpoint for cellular activation. Prospective evaluation of this assay in a larger cohort of patients is awaited.

\section{An Evidence-Based Bayesian Approach to Diagnosis}

The diagnostic tools most widely available to clinicians are clinical assessment and the PF4/heparin ELISA. ${ }^{77}$ An

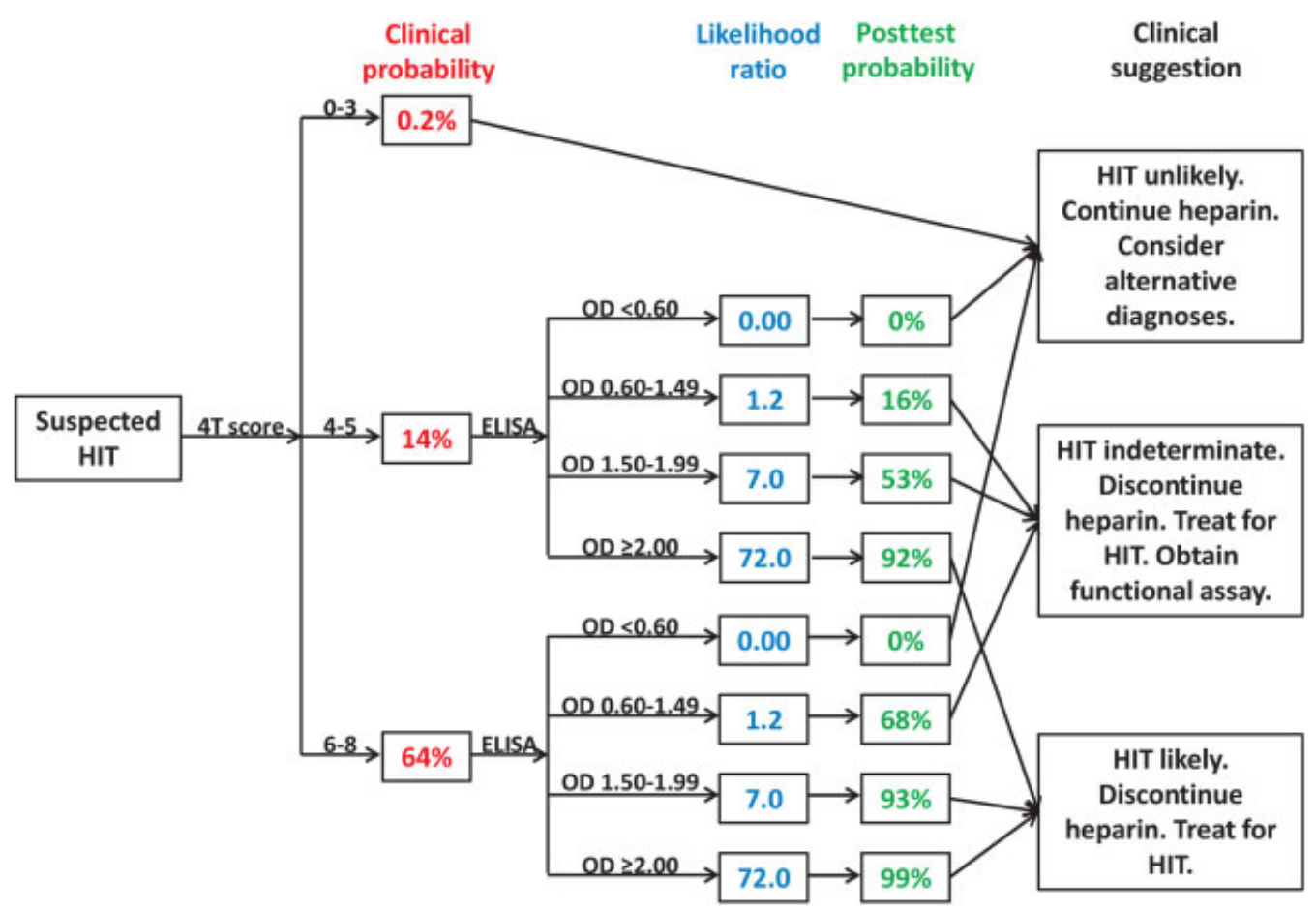

Fig. 1 Evidence-based Bayesian approach to the diagnosis of HIT. The figure depicts one approach to the evaluation of patients with suspected HIT. Clinical probability estimates for a low (0-3), intermediate (4-5), and high (6-8) probability 4 T score, derived from a meta-analysis, ${ }^{29}$ are shown. Patients with a low probability 4T score have a very low likelihood of HIT and do not require HIT laboratory testing. Testing with a sensitive immunoassay should be considered in patients with an intermediate or high probability score. If an ELISA is performed, the OD may be used to refine the estimated probability of HIT. Likelihood ratios for various OD strata are shown. These likelihood ratios were derived using a commercially available polyspecific ELISA (GTI PF4 Enhanced, Gen-Probe GTI Diagnostics, Waukesha, WI) in a single institution and may not apply to other assays or other laboratories. ${ }^{44}$ The clinical probability (after conversion to clinical odds) may be multiplied by the likelihood ratio to estimate the posttest odds of HIT (which, in turn, may be converted to posttest probability). For simplicity, only probabilities (and not odds) are shown. Clinical suggestions for further evaluation and management based on the estimated probability of HIT are provided. This approach may be used as a guide, but it should not supersede clinical judgment. 
evidence-based Bayesian approach that integrates the 4T score and the OD value determined by PF4/heparin ELISA testing may be used to estimate the posttest probability of HIT and guide clinical decision-making.

One such approach is depicted in - Fig. 1. In this approach, the 4Ts score is used to estimate the clinical (pretest) probability of HIT. Patients with a low probability 4Ts score have a very low likelihood of HIT and do not require HIT laboratory testing. Testing with a sensitive immunoassay should be considered in patients with an intermediate or high probability score. If an ELISA is performed, the OD may be used to refine the estimated probability of HIT. The clinical probability and likelihood ratio associated with a given OD value may be used to estimate the posttest probability of HIT. The estimated probability of HIT, in turn, may inform decisions about further clinical evaluation and management.

\section{Conclusion}

Rapid and accurate diagnosis of HIT is both challenging and of critical clinical importance. Clinical scoring systems such as the 4Ts and HEP score have high negative predictive value and permit an estimation of the clinical probability of HIT but have limited specificity and have not been directly compared with standard intuition-based clinical diagnosis. Similar to clinical scoring systems, immunoassays are highly sensitive, but they lack adequate specificity at manufacturer-recommended cutoffs to rule in HIT. Washed platelet functional assays are both sensitive and specific, but they are restricted to select reference laboratories due to meticulous technical requirements. The need for fresh and responsive donor platelets also restricts the use of these assays and remains a potential source of poor performance in inexperienced hands.

Evidence-based Bayesian approaches to diagnosis that integrate clinical assessment and immunoassay testing, the two most widely used diagnostic tools in current practice, facilitate estimation of the posttest probability of HIT, and may guide clinical decision making (-Fig. 1). Also in development are novel laboratory tests that are less technically demanding, more specific, do not rely on fresh responsive donor platelets and have shorter TATs than existing assays. These advancements are likely to presage more exacting diagnosis and management and better outcomes for patients with suspected HIT.

\section{Acknowledgment}

This work was supported by HL112903 to AC.

\section{References}

1 Amiral J, Bridey F, Dreyfus M, et al. Platelet factor 4 complexed to heparin is the target for antibodies generated in heparin-induced thrombocytopenia. Thromb Haemost 1992;68(1):95-96

2 Rauova L, Poncz M, McKenzie SE, et al. Ultralarge complexes of PF4 and heparin are central to the pathogenesis of heparin-induced thrombocytopenia. Blood 2005;105(1):131-138
3 Cines DB, Tomaski A, Tannenbaum S. Immune endothelial-cell injury in heparin-associated thrombocytopenia. N Engl J Med 1987;316(10):581-589

4 Kasthuri RS, Glover SL, Jonas W, et al. PF4/heparin-antibody complex induces monocyte tissue factor expression and release of tissue factor positive microparticles by activation of FcrRI. Blood 2012;119(22):5285-5293

5 Linkins LA, Dans AL, Moores LK, et al. Treatment and prevention of heparin-induced thrombocytopenia: antithrombotic therapy and prevention of thrombosis. 9th ed. American College of Chest Physicians Evidence-Based Clinical Practice Guidelines. Chest 2012;141:e495S-e530S

6 Cuker A, Cines DB. How I treat heparin-induced thrombocytopenia. Blood 2012;119(10):2209-2218

7 Cuker A. Current and emerging therapeutics for heparin-induced thrombocytopenia. Semin Thromb Hemost 2012;38(1):31-37

8 Greinacher A, Eichler P, Lubenow N, Kwasny H, Luz M. Heparininduced thrombocytopenia with thromboembolic complications: meta-analysis of 2 prospective trials to assess the value of parenteral treatment with lepirudin and its therapeutic aPTT range. Blood 2000;96(3):846-851

9 Warkentin TE, Kelton JG. A 14-year study of heparin-induced thrombocytopenia. Am J Med 1996;101(5):502-507

10 Wallis DE, Workman DL, Lewis BE, Steen L, Pifarre R, Moran JF. Failure of early heparin cessation as treatment for heparin-induced thrombocytopenia. Am J Med 1999;106(6):629-635

11 Cuker A. Heparin-induced thrombocytopenia (HIT) in 2011: an epidemic of overdiagnosis. Thromb Haemost 2011;106(6):993-994

12 Lewis BE, Wallis DE, Hursting MJ, Levine RL, Leya F. Effects of argatroban therapy, demographic variables, and platelet count on thrombotic risks in heparin-induced thrombocytopenia. Chest 2006;129(6):1407-1416

13 Lubenow N, Eichler P, Lietz T, Greinacher A; Hit Investigators Group. Lepirudin in patients with heparin-induced thrombocytopenia - results of the third prospective study (HAT-3) and a combined analysis of HAT-1, HAT-2, and HAT-3. J Thromb Haemost 2005;3(11):2428-2436

14 Magnani HN, Gallus A. Heparin-induced thrombocytopenia (HIT) A report of 1,478 clinical outcomes of patients treated with danaparoid (Orgaran) from 1982 to mid-2004. Thromb Haemost 2006;95(6):967-981

15 Warkentin TE, Greinacher A, Gruel Y, Aster RH, Chong BH; Scientific and Standardization Committee of the International Society on Thrombosis and Haemostasis. Laboratory testing for heparininduced thrombocytopenia: A conceptual framework and. implications for diagnosis. J Thromb Haemost 2011;9:2498-2500

16 Oliveira GB, Crespo EM, Becker RC, et al; Complications After Thrombocytopenia Caused by Heparin (CATCH) Registry Investigators. Incidence and prognostic significance of thrombocytopenia in patients treated with prolonged heparin therapy. Arch Intern Med 2008;168(1):94-102

17 Girolami B, Prandoni P, Stefani PM, et al. The incidence of heparininduced thrombocytopenia in hospitalized medical patients treated with subcutaneous unfractionated heparin: a prospective cohort study. Blood 2003;101(8):2955-2959

18 Büller HR, Davidson BL, Decousus H, et al; Matisse Investigators. Subcutaneous fondaparinux versus intravenous unfractionated heparin in the initial treatment of pulmonary embolism. N Engl J Med 2003;349(18):1695-1702

19 Morris TA, Castrejon S, Devendra G, Gamst AC. No difference in risk for thrombocytopenia during treatment of pulmonary embolism and deep venous thrombosis with either low-molecular-weight heparin or unfractionated heparin: a metaanalysis. Chest 2007; 132(4):1131-1139

20 Prandoni P, Siragusa S, Girolami B, Fabris F; BELZONI Investigators Group. The incidence of heparin-induced thrombocytopenia in medical patients treated with low-molecular-weight heparin: a prospective cohort study. Blood 2005;106(9):3049-3054 
21 Hui P, Cook DJ, Lim W, Fraser GA, Arnold DM. The frequency and clinical significance of thrombocytopenia complicating critical illness: a systematic review. Chest 2011;139(2):271-278

22 Crowther MA, Cook DJ, Meade MO, et al. Thrombocytopenia in medical-surgical critically ill patients: prevalence, incidence, and risk factors. J Crit Care 2005;20(4):348-353

23 Cook D, Meade M, Guyatt G, et al; PROTECT Investigators for the Canadian Critical Care Trials Group and the Australian and New Zealand Intensive Care Society Clinical Trials Group. Dalteparin versus unfractionated heparin in critically ill patients. N Engl J Med 2011;364(14):1305-1314

24 Crowther MA, Cook DJ, Albert M, et al; Canadian Critical Care Trials Group. The 4Ts scoring system for heparin-induced thrombocytopenia in medical-surgical intensive care unit patients. J Crit Care 2010;25(2):287-293

25 Verma AK, Levine M, Shalansky SJ, Carter CJ, Kelton JG. Frequency of heparin-induced thrombocytopenia in critical care patients. Pharmacotherapy 2003;23(6):745-753

26 Cuker A. Heparin-induced thrombocytopenia: present and future. J Thromb Thrombolysis 2011;31(3):353-366

27 Warkentin TE, Heddle NM. Laboratory diagnosis of immune heparin-induced thrombocytopenia. Curr Hematol Rep 2003; 2(2):148-157

28 Lo GK, Juhl D, Warkentin TE, Sigouin CS, Eichler P, Greinacher A. Evaluation of pretest clinical score ( $\left.4 \mathrm{~T}^{\prime} \mathrm{s}\right)$ for the diagnosis of heparin-induced thrombocytopenia in two clinical settings. J Thromb Haemost 2006;4(4):759-765

29 Cuker A, Gimotty PA, Crowther MA, Warkentin TE. Predictive value of the 4Ts scoring system for heparin-induced thrombocytopenia: a systematic review and meta-analysis. Blood 2012;120(20): 4160-4167

30 Cuker A, Arepally G, Crowther MA, et al. The HIT Expert Probability (HEP) Score: a novel pre-test probability model for heparininduced thrombocytopenia based on broad expert opinion. J Thromb Haemost 2010;8(12):2642-2650

31 Strutt JK, Mackey JE, Johnson SM, Sylvia LM. Assessment of the 4Ts pretest clinical scoring system as a predictor of heparin-induced thrombocytopenia. Pharmacotherapy 2011;31(2):138-145

32 Nagler M, Fabbro T, Wuillemin WA. Prospective evaluation of the interobserver reliability of the 4Ts score in patients with suspected heparin-induced thrombocytopenia. J Thromb Haemost 2012; 10(1):151-152

33 Uaprasert N, Chanswangphuwana C, Akkawat B, Rojnuckarin P. Comparison of diagnostic performance of the heparin-induced thrombocytopenia expert probability and the 4Ts score in screening for heparin-induced thrombocytopenia. Blood Coagul Fibrinolysis 2013;24(3):261-268

34 Farahani N, Kitahara S, Tcherniantchouk O. Prospective comparison of the HIT expert probability (HEP) score versus the Warkentin $4 \mathrm{~T}$ 's score in a quaternary care center. [abstract]J Thromb Haemost 2013;11(s2):936

35 Lillo-Le Louët A, Boutouyrie P, Alhenc-Gelas M, et al. Diagnostic score for heparin-induced thrombocytopenia after cardiopulmonary bypass. J Thromb Haemost 2004;2(11):1882-1888

36 Messmore HL, Fabbrini N, Bird ML, et al. Simple scoring system for early management of heparin-induced thrombocytopenia. Clin Appl Thromb Hemost 2011;17(2):197-201

37 Piednoir $\mathrm{P}$, Allou N, Provenchère $\mathrm{S}$, et al. Heparin-induced thrombocytopenia after cardiac surgery: an observational study of 1,722 patients. J Cardiothorac Vasc Anesth 2012;26(4): 585-590

38 Bakchoul T, Giptner A, Najaoui A, Bein G, Santoso S, Sachs UJ. Prospective evaluation of PF4/heparin immunoassays for the diagnosis of heparin-induced thrombocytopenia. J Thromb Haemost 2009;7(8):1260-1265

39 Lo GK, Sigouin CS, Warkentin TE. What is the potential for overdiagnosis of heparin-induced thrombocytopenia? Am J Hematol 2007;82(12):1037-1043
40 Greinacher A, Juhl D, Strobel U, et al. Heparin-induced thrombocytopenia: a prospective study on the incidence, platelet-activating capacity and clinical significance of antiplatelet factor 4/ heparin antibodies of the IgG, IgM, and IgA classes. J Thromb Haemost 2007;5(8):1666-1673

41 Juhl D, Eichler P, Lubenow N, Strobel U, Wessel A, Greinacher A. Incidence and clinical significance of anti-PF4/heparin antibodies of the IgG, IgM, and IgA class in 755 consecutive patient samples referred for diagnostic testing for heparin-induced thrombocytopenia. Eur J Haematol 2006;76(5):420-426

42 Zwicker JI, Uhl L, Huang WY, Shaz BH, Bauer KA. Thrombosis and ELISA optical density values in hospitalized patients with heparininduced thrombocytopenia. J Thromb Haemost 2004;2(12): 2133-2137

43 Warkentin TE, Sheppard JI, Moore JC, Sigouin CS, Kelton JG. Quantitative interpretation of optical density measurements using PF4-dependent enzyme-immunoassays. J Thromb Haemost 2008; 6(8):1304-1312

44 Raschke RA, Curry SC, Warkentin TE, Gerkin RD. Improving clinical interpretation of the anti-platelet factor 4/heparin enzyme-linked immunosorbent assay for the diagnosis of heparin-induced thrombocytopenia through the use of receiver operating characteristic analysis, stratum-specific likelihood ratios, and bayes theorem. Chest 2013;144(4):1269-1275

45 Cuker A, Ortel TL. ASH evidence-based guidelines: is the IgGspecific anti-PF4/heparin ELISA superior to the polyspecific ELISA in the laboratory diagnosis of HIT? Hematology (Am Soc Hematol Educ Program) 2009; $\cdots *: 250-252$

46 Whitlatch NL, Kong DF, Metjian AD, Arepally GM, Ortel TL. Validation of the high-dose heparin confirmatory step for the diagnosis of heparin-induced thrombocytopenia. Blood 2010; 116(10):1761-1766

47 Warkentin TE, Sheppard JI. No significant improvement in diagnostic specificity of an anti-PF4/polyanion immunoassay with use of high heparin confirmatory procedure. J Thromb Haemost 2006; 4(1):281-282

48 Selleng S, Schreier N, Wollert HG, Greinacher A. The diagnostic value of the anti-PF4/heparin immunoassay high-dose heparin confirmatory test in cardiac surgery patients. Anesth Analg 2011; 112(4):774-776

49 Sachais BS, Litvinov RI, Yarovoi SV, et al. Dynamic antibodybinding properties in the pathogenesis of HIT. Blood 2012; 120(5):1137-1142

50 Cuker A, Rux AH, Hinds JL, et al. Novel diagnostic assays for heparininduced thrombocytopenia. Blood 2013;121(18):3727-3732

51 Sachs UJ, von Hesberg J, Santoso S, Bein G, Bakchoul T. Evaluation of a new nanoparticle-based lateral-flow immunoassay for the exclusion of heparin-induced thrombocytopenia (HIT). Thromb Haemost 2011;106(6):1197-1202

52 Meyer O, Salama A, Pittet N, Schwind P. Rapid detection of heparininduced platelet antibodies with particle gel immunoassay (IDHPF4). Lancet 1999;354(9189):1525-1526

53 Bakchoul T, Giptner A, Najaoui A, Bein G, Santoso S, Sachs UJH. Prospective evaluation of PF4/heparin immunoassays for the diagnosis of heparin-induced thrombocytopenia. J Thromb Haemost 2009;7(8):1260-1265

54 Davidson SJ, Ortel TL, Smith LJ. Performance of a new, rapid, automated immunoassay for the detection of anti-platelet factor 4/heparin complex antibodies. Blood Coagul Fibrinolysis 2011; 22(4):340-344

55 Althaus K, Hron G, Strobel U, et al. Evaluation of automated immunoassays in the diagnosis of heparin induced thrombocytopenia. Thromb Res 2013;131(3):e85-e90

56 Legnani C, Cini M, Pili C, Boggian O, Frascaro M, Palareti G. Evaluation of a new automated panel of assays for the detection of anti-PF4/heparin antibodies in patients suspected of having heparin-induced thrombocytopenia. Thromb Haemost 2010; 104(2):402-409 
57 Van Hoecke F, Devreese K. Evaluation of two new automated chemiluminescent assays (HemosIL ${ }^{\circledR}$ AcuStar HIT-IgG and HemoSIL ${ }^{\circledR}$ AcuStar HIT-Ab) for the detection of heparin-induced antibodies in the diagnosis of heparin-induced thrombocytopenia. Int J Lab Hematol 2012;34(4):410-416

58 Warkentin TE, Greinacher A. Laboratory testing for heparin-induced thrombocytopenia. In: Warkentin TE, Greinacher A, eds Heparin-Induced Thrombocytopenia. Boca Raton Informa; 2013: 272-314

59 Warkentin TE, Sheppard JI, Raschke RA, Greinacher A. Performance characteristics of a rapid assay for anti-PF4/heparin antibodies: the particle immunofiltration assay. J Thromb Haemost 2007; 5(11):2308-2310

60 Sheridan D, Carter C, Kelton JG. A diagnostic test for heparininduced thrombocytopenia. Blood 1986;67(1):27-30

61 Greinacher A, Michels I, Kiefel V, Mueller-Eckhardt C. A rapid and sensitive test for diagnosing heparin-associated thrombocytopenia. Thromb Haemost 1991;66(6):734-736

62 Stewart MW, Etches WS, Boshkov LK, Gordon PA. Heparin-induced thrombocytopenia: an improved method of detection based on lumi-aggregometry. Br J Haematol 1995;91(1):173-177

63 Lee DH, Warkentin TE, Denomme GA, Hayward CPM, Kelton JG. A diagnostic test for heparin-induced thrombocytopenia: detection of platelet microparticles using flow cytometry. $\mathrm{Br} \mathrm{J}$ Haematol 1996;95(4):724-731

64 Nazi I, Arnold DM, Smith JW, et al. FcyRIIa proteolysis as a diagnostic biomarker for heparin-induced thrombocytopenia. J Thromb Haemost 2013;11(6):1146-1153

65 Chong BH, Burgess J, Ismail F. The clinical usefulness of the platelet aggregation test for the diagnosis of heparin-induced thrombocytopenia. Thromb Haemost 1993;69(4):344-350

66 Cines DB, Kaywin P, Bina M, Tomaski A, Schreiber AD. Heparinassociated thrombocytopenia. N Engl J Med 1980;303(14):788-795

67 Tomer A. A sensitive and specific functional flow cytometric assay for the diagnosis of heparin-induced thrombocytopenia. $\mathrm{Br} \mathrm{J}$ Haematol 1997;98(3):648-656
68 Gobbi G, Mirandola P, Tazzari PL, et al. Flow cytometry detection of serotonin content and release in resting and activated platelets. $\mathrm{Br}$ J Haematol 2003;121(6):892-896

69 Vitale M, Tazzari P, Ricci F, et al. Comparison between different laboratory tests for the detection and prevention of heparininduced thrombocytopenia. Cytometry 2001;46(5):290-295

70 Mullier F, Bailly N, Cornet Y, et al. Contribution of platelet microparticles generation assay to the diagnosis of type II heparininduced thrombocytopenia. Thromb Haemost 2010;103(6): 1277-1281

71 Favaloro EJ, Bernal-Hoyos E, Exner T, Koutts J. Heparin-induced thrombocytopenia: laboratory investigation and confirmation of diagnosis. Pathology 1992;24(3):177-183

72 Greinacher A, Amiral J, Dummel V, Vissac A, Kiefel V, MuellerEckhardt C. Laboratory diagnosis of heparin-associated thrombocytopenia and comparison of platelet aggregation test, heparininduced platelet activation test, and platelet factor 4/heparin enzyme-linked immunosorbent assay. Transfusion 1994;34(5): 381-385

73 Morel-Kopp MC, Tan CW, Brighton TA, et al; ASTH Clinical Trials Group. Validation of whole blood impedance aggregometry as a new diagnostic tool for HIT: results of a large Australian study. Thromb Haemost 2012;107(3):575-583

74 Prechel M, Walenga JM. Heparin-induced thrombocytopenia: an update. Semin Thromb Hemost 2012;38(5):483-496

75 Price EA, Hayward CP, Moffat KA, Moore JC, Warkentin TE, Zehnder JL. Laboratory testing for heparin-induced thrombocytopenia is inconsistent in North America: a survey of North American specialized coagulation laboratories. Thromb Haemost 2007; 98(6):1357-1361

76 Sachais BS, Rux AH, Cines DB, et al. Rational design and characterization of platelet factor 4 antagonists for the study of heparininduced thrombocytopenia. Blood 2012;119(25):5955-5962

77 Tan CW, Ward CM, Morel-Kopp MC. Evaluating heparin-induced thrombocytopenia: the old and the new. Semin Thromb Hemost 2012;38(2):135-143 